\title{
VET or general education? Effects of regional opportunity structures on educational attainment in German-speaking Switzerland
}

\author{
David Glauser $^{1 *}$ (D) and Rolf Becker ${ }^{1,2}$
}

*Correspondence:

david.glauser@edu.unibe.ch

${ }^{1}$ Institute of Educational

Science, University of Bern,

Fabrikstrasse 8, 3012 Bern,

Switzerland

Full list of author information is available at the end of the article

\begin{abstract}
Background: Regional opportunity structures have received little attention in research on educational aspirations and attainment. This papers aim is to address whether regional opportunity structures affect educational attainment at the transition from lower to upper secondary education net of institutional and individual effects. Related with this issue we also ask how opportunity structures influence pupils' educational attainment.

Methods: We use data of the DAB panel study that contains information on pupils' educational aspirations as well as their actual educational attainment immediately after as well as 15 months after leaving compulsory schooling $(N=2.192)$. In order to account for regional variation of the opportunity structures we construct one scaling variable based on principal component factor analysis and merge these with DAB data. In the scaling variable, various aspects of the regional labor market structures and conditions, as well as the diversity and extent of the supply of educational alternatives, are considered. Educational outcomes are analyzed using multinomial logistic regression models.

Results: Our results indicate, first, that the more extensive regional opportunity structures are, the higher the probability of pupils attending general education programs. In contrast, restricted opportunity structures increase pupils' probability of attending VET. Second, regional opportunity structures are perceived, subjectively evaluated and organize a pupil's set of feasible actions and educational attainment: on the one hand regional opportunity structures are correlated with pupils' realistic educational aspirations. Once we control for educational aspirations the direct effects of opportunity structures on educational attainment after leaving compulsory schooling can be partially explained.
\end{abstract}

Keywords: School-to-work, Upper secondary education, Opportunity structures, Educational aspirations, Inequality of educational opportunities

\section{Background}

The transition from school-to-work and, consequently, the acquisition of vocational or general qualifications, is an important step in the life of adolescents with respect to their subsequent educational opportunities and career prospects over the life course. Due to 
the long lasting consequences, school-to-work related inequality of educational opportunity (IEO) has been a key subject of empirical educational research for years. On the one hand, educational opportunities depend on and are provided by the organization of a specific educational system, i.e., the degree of stratification, standardization, vocational specificity, and permeability. On the other hand, IEO is partially explained by the differential societal orders and contexts in which pupils are embedded: social origins, peer-groups, school classes, etc. Also significant-although often neglected-are regional opportunity structures that may encourage pupils to take up vocational education and training (VET) rather than continuing with general education. These include: the regional supply of VET and general education programs, local labor market conditions, the size of the school-leaver cohort, and competition among pupils for a small number of apprenticeships or general education programs.

Therefore, we focus on the relevance of regional opportunity structures to the actual decision as to whether to begin VET or general education programs at the transition from compulsory to upper secondary education in German-speaking Switzerland. In order to explain disparities at this particular educational transition, we not only control for individual characteristics (social origins, GPA, educational aspirations, gender) and institutional constraints (type of school attended at lower secondary level) but also use macro level data to consider the regional opportunity structure. Even if the available administrative data are far from perfect, we address the question of whether and in what direction regional opportunity structures-in addition to constraints at the individual and institutional levels-affect pupils in their decision to attend either VET or general education programs. In addition and related to this issue, we focus on how opportunity structures influence pupils' educational attainment.

This paper is structured as follows: In the second section, we describe the education and training alternatives available under the Swiss education system. In section three, we describe our theoretical model, which accounts for individual, institutional, and regional constraints and opportunities in order to explain the educational attainment of youths and to establish the micro-macro-link. Subsequently, we explicate our data, the operationalization of the variables used in the multivariate analyses, and the statistical procedure. We then discuss the analytical results concerning the educational situation of youths both immediately after and 15 months after leaving compulsory education. In our conclusion, we draw attention to the limitations of our results and to potential areas for further research.

\section{Educational alternatives after compulsory schooling}

Upper secondary education in Switzerland begins after 9th grade (for a schematic representation of the Swiss education system, see Fig. 2 in the Appendix). The majority-approximately $70 \%$ - of the school leaver cohorts then begin either dual apprenticeships or school-based vocational education and training programs in which they acquire occupation-specific qualifications. Depending on their school performance and the school track they attended at lower secondary level, pupils can choose from approximately 240 different VET programs. Apprenticeships or school-based VET programs can be completed either within 2 (Federal VET Certificate, EBA) or 3-4 years (Federal VET Diploma, EFZ; Federal Vocational Baccalaureate Certificate, FVB). An increasing 
proportion of pupils now takes the FVB, which places greater emphasis on general education. The FVB can be obtained during or upon completion of a Federal VET Diploma. General full time education is provided at baccalaureate schools (Gymnasiale Maturitätsschulen) and at specialized schools (Fachmittelschulen, FMS), although the curricula of the latter are focused more on providing occupation-specific skills. Graduates of the FVB or FMS are eligible for direct admission to universities of applied sciences, whereas students with matriculation certificates are entitled to enroll at universities.

The distribution of upper secondary qualifications attained in German-speaking Swit-

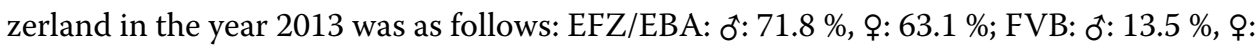
$12.5 \%$; baccalaureate and specialized schools: $0: 14.7 \%$, ᄋ: $24.4 \%$ (BFS 2014, owncalculations). Pupils who-for whatever reason-are unable to immediately commence a certifying upper secondary VET or general education program after compulsory schooling are provided with opportunities to begin different types of bridge year course, e.g., 10th school year, au-pair, pre-apprenticeships, preparatory courses for particular education programs, etc. These non-mandatory bridge year courses are accessed by approximately $20 \%$ of the school leaver cohorts (Hupka 2003; Glauser 2015). Finally, entering the labor market without acquiring additional qualifications or not being in education, employment, or training (NEET) are rarely used alternatives.

Because the Swiss education system is highly stratified and tracking into different school types after primary school already begins after 6th grade in most cantons, the room for maneuver in making educational decisions towards the end of compulsory education depends on the type of school attended. Educational opportunities for pupils from the school type with basic requirements-i.e., the school type with the lowest cognitive demands at lower secondary level-are mainly restricted to VET programs with a shorter duration and/or lower cognitive requirements (EBA, EFZ), and these students face the highest risk of accessing bridge year courses (Meyer 2003; Glauser 2015). In contrast, pupils who attend a school type with advanced requirements formally have the option to commence a wide range of VET programs (EBA, EFZ, FVB) or baccalaureate and specialized schools, respectively. The vast majority of pupils from baccalaureate preparation schools (pre-gymnasium) continue with general education programs (baccalaureate or specialized schools).

Compared to other OECD countries, a rather smooth school-to-work transition can be observed for Switzerland (Blöchle et al. 2015; OECD 2015). The majority of youths who have completed VET gain access to permanent, secure, and relatively well-paid positions within a short timeframe (Müller and Schweri 2009; Glauser 2012; Lange et al. 2013). Due to the expansion of the universities of applied sciences and the long tradition of the Swiss VET-system, a broad range of vocationally oriented further training is available at post-secondary and tertiary level. Nonetheless, the permeability between vocationally and academically oriented tracks at secondary and tertiary level is low (Fazekas and Field 2013, 71, SKBF 2014, 172). Since graduation from baccalaureate schools entitles graduates to enroll at universities, those who opt for academically oriented tracks and graduate from university on average earn more and have more opportunities to gain access to higher social classes and to attain a more privileged way of life (Buchmann et al. 2007; Müller et al. 2011; Schindler, 2014). 


\section{Theory and research}

Educational pathways in an individual's life course are embedded in varying societal orders and social contexts, which, at the same time, systematically affect the duration of participation in education and the opportunities to select and complete certain educational pathways (Coleman 1986; Becker and Hadjar 2013; Becker and Schulze 2013). Therefore, in order to explain the educational decisions made at the transition to upper secondary education, individual, institutional, and regional constraints and opportunities need to be considered (see Fig. 1). In this section, we first explicate how the nexus of education and the employment system is generating institutionalized educational pathways that are accompanied by specific opportunities and constraints with regard to further education and working careers. Second, we elaborate on how disparities in the social structure of educational attainment can be explained within a structural-individualistic theoretical framework. Finally, we clarify how educational aspirations and decisions may be related to regional opportunities and constraints.

\section{Impact of the institutional setting}

In the Swiss context, educational pathways and trajectories at upper secondary and subsequent levels are highly institutionalized, particularly those in which occupationspecific skills are of greater importance. As in other countries with a system of "qualificational space" (Maurice et al. 1986), a relatively high proportion of firms is engaged in training apprentices and their organization of labor is aligned with qualifications acquired in VET programs (Wolter et al. 2006). Furthermore, training companies have a determining influence on the curricula of specific VET programs about branch associations (Gonon 2012, 239). Albeit with a delay, changes in the business cycle, the structure of the labor market, as well as the occupational structure likewise affect the qualifications that are acquired in existing or newly created apprenticeships. Due to the high degree of vocational specificity and standardization, firms can rely on the

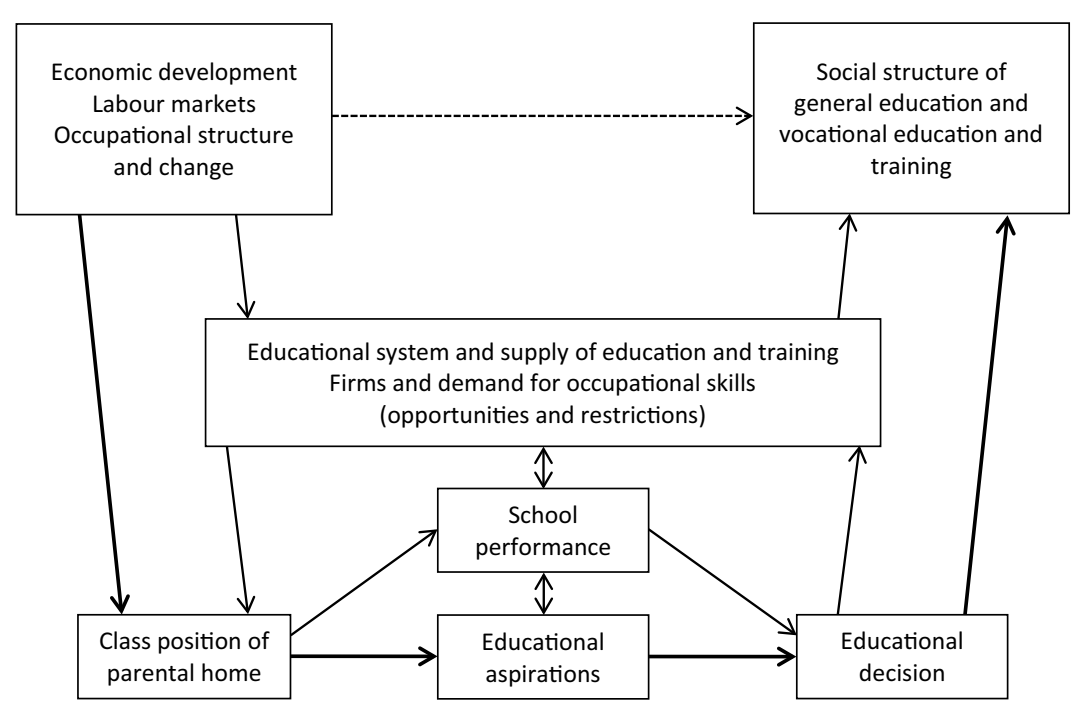

Fig. 1 Heuristic micro-macro model to explain the social structure of upper secondary education 
acquired occupation-specific qualifications when filling vacant posts (Müller and Shavit 1998; Kerckhoff 2001; Wolter et al. 2006). This, in turn, implies that VET-qualifications determine a candidate's initial placement in the labor market, as well as the subsequent opportunities related to continued professional development and occupational mobility between firms and occupations (Blossfeld 1985; Gangl 2001; Schmelzer 2012; Müller and Schweri 2015). On the other hand, if pupils opt for VET, their chance of acquiring a secure, qualified, and well-paid job is much higher compared to low-skilled workers (Müller and Schweri 2009; Meyer and Bertschy 2011; Glauser 2012; Lange et al. 2013). These aspects, as well as the long tradition of VET, partly explain why vocational qualifications are well-respected in Switzerland, and why approximately two thirds of the school leaver cohorts decide in favor of vocational training. Pupils' feasible set of vocational alternatives is restricted not only in terms of the type of school attended at lower secondary level but the recruitment strategy and selection criteria of employers when filling vacant apprenticeships. In this respect, the access to dual apprenticeships is a special case of the 'matching-problem' between employers and employees at the point of labor market entry (Müller et al. 2002).

In contrast, admission criteria and/or entrance examinations of school-based apprenticeships, FVB, or general education programs are regulated at the cantonal level. Although admission depends on school performance, the provision of baccalaureate schools, in German-speaking cantons in particular, has not changed much over time. The matura rate in German-speaking Switzerland has remained relatively stable at approximately $20 \%$ in the last 15 years and is approximately $8 \%$ lower than in French- and Italian-speaking areas (Becker and Zangger 2013; BFS 2015; Glauser 2015). The proportion of VET graduates within a canton is not only negatively correlated with the probability of enrollment at baccalaureate and specialized schools but also with the probability of attaining a tertiary degree (Imdorf et al. 2014). Pupils who fail to meet the selection criteria of baccalaureate or specialized schools must consider other educational options, namely VET programs or bridge year courses.

\section{Individual resources and restrictions}

In countries with a high degree of stratification and vocational specificity, a close relationship is observed between social origin and educational attainment, while intergenerational educational mobility is comparatively low (Pfeffer 2008; Müller and Kogan 2010; Falter and Wendelspiess Chávez Juárez 2011; Jann and Combet 2012; Falcon 2012; Becker and Zangger 2013; Samuel et al. 2014). Children from socially underprivileged families are less likely to succeed in directly securing a certifying upper secondary training place (Sacchi et al. 2011; Müller and Wolter 2014), and they are under-represented at baccalaureate schools and the FVB (Schumann 2011; Stalder et al. 2011).

Social disparity with regard to lower and upper secondary educational attainment can be explained to some extent within a structural individualistic theoretical framework (Boudon 1974; Becker 2003; Stocké 2010; Kroneberg and Kalter 2012). Social inequalities in educational attainment result from the correlation between social background and school performance (primary effect of stratification). As a consequence of early tracking, during compulsory education, pupils from socially disadvantaged families are overrepresented in school types with lower requirements and, accordingly, in vocationally 
oriented tracks at subsequent educational levels. However, IEO occurs even if school performance is controlled for. This is referred to as the secondary effect of stratification and describes the rationale behind educational decision-making, which varies between actors from different social strata. All things being equal-as measured, for example, by grade point averages (GPAs) - pupils from socially disadvantaged families are diverted from academically oriented tracks and instead opt for VET. The reason is that students from lower social classes, if they can choose between educational alternatives, tend to prefer less demanding, time-consuming, costly, and risky educational tracks that nevertheless secure their access to qualified occupational positions and protect them against unemployment (Müller and Pollak 2007; Breen et al. 2014). By contrast, educational aspirations to continue with general education are higher among pupils from socially privileged families because they otherwise face downward social mobility, the financial burdens are lower, and they are familiar with general education (Erikson and Jonsson 1996; Breen and Goldthorpe 1997). These theoretical assumptions are supported by empirical results for different educational transitions and within a variety of educational systems (representative of many: Stocké 2007; Erikson and Rudolphi 2010; Combet 2013; Karlson 2013; Becker et al. 2013; Glauser 2015).

\section{Regional opportunity structures}

So far, regional opportunity structures have received little attention in research on educational aspirations and decisions at the transition to upper secondary education. If the impact of regional conditions of the labor market, the educational setting, or other spatial aspects is considered, the focus has been on the transition from elementary to lower secondary education (Sixt 2013; Zangger 2015), the decision to commence tertiary education (Rephann 2002; Denzler and Wolter 2009; Reimer 2013), labor market entry (Salvisberg and Sacchi 2014; Buchs et al. 2015), or the decision by firms to train apprentices (Muhlemann and Wolter 2007). To our knowledge, the study from Weßling et al. (2015) is the only one that focuses on regional labor market effects on opportunities to commence VET after compulsory education. With regard to Germany, the results indicate that opportunities to commence VET are negatively correlated with the local unemployment rate but uncorrelated with the labor market conditions of more remote areas. However, what the authors cannot address with the SOEP-data is the question of whether educational aspirations prior to the actual transition are likewise affected by regional labor market conditions.

Regarding the decision to commence VET or general education, we assume that pupils (and their parents) take the regional opportunity structures into account. The opportunity structures of the region in which they reside deliver information on opportunities and constraints related to different educational alternatives. This information, we assume, influences their educational aspirations and final decisions. Variation in the opportunity structures across regions should thus (partly) explain the variation observed in pupils' educational aspirations as well as the upper secondary track they attend (hypothesis 1). The question as to whether these opportunity structures have an impact on the educational attainment net of individual resources and the institutional setting of the education system needs to be answered empirically. 
Based on the discussion above, we argue that regional opportunity structures in Switzerland differ with respect to the diversity and extent of the supply of educational alternatives. On the other hand, due to the strongly developed VET system and the strong ties between the education system and labor market, the feasible set of educational alternatives depends on the condition as well as the structure of the regional labor market. Therefore, regions that differ in terms of occupational structure, relative importance of labor market sectors, and dynamics of the labor market provide varying opportunity structures. In regards to upper secondary educational attainment, we expect the following: The more extensive the regional opportunity structures are, the higher the probability that pupils opt for general education programs (hypothesis 2). We argue that regions that can be characterized by more extensive opportunity structures provide a broader range of not only vocationally but also academically oriented educational alternatives as well as bridge year courses. Additionally, in these regions, the proportion of occupations and workplaces in the third sector has significantly increased in the last few decades. This development has deteriorated to some extent the employment prospects of persons with vocational qualifications (Oesch 2013; Murphy 2014). The reason is that, when filling vacant posts that can be assigned to the third sector, firms prefer graduates from school based training rather than graduates from dual VET, and their willingness to train apprentices has decreased (Sheldon 2008; Salvisberg and Sacchi 2014). In contrast, due to the trajectory of historical development, the widest range of apprenticeships exists, even today, within the commercial and industrial sectors (Gonon 2012). Accordingly, in regions in which the second sector of the labor market remains of great importance, the opportunity structures may divert pupils from attending a general education program.

\section{Methods}

Data

To analyze the transition from lower to upper secondary education, we use recent data from the DAB panel study (Determinants of educational choices and vocational training opportunities). The focus of the DAB panel study is on the decision-making process and educational pathways of pupils that left compulsory education in summer 2013. The data are based on a stratified random sample of classes of 8th graders of the 2011/12 school year within German-speaking Switzerland (for details, see (Glauser 2015), 125-132). The survey time points were in the middle of the 8th grade (Jan/Feb 2012) as well as at the beginning (Sept/Oct 2012) and end (May/June 2013) of the final year of compulsory education. Data on the actual transition were collected in a follow-up study approximately 15 months after pupils had left lower secondary education in October/November 2014. While in the first three waves the students were surveyed within their classes using online questionnaires, the follow-up was conducted as an individual survey, using a combination of online questionnaires and computer assisted telephone interviews (CATI). At the class level, 215 to 199 out of the 296 classes sampled (72.6-67.2\%) and, at the individual level, approximately $3700-3300$ students (response rates within waves: 90-96 \%) participated in the first three waves. Due to missing contact information, 2550 out of 3302 pupils who participated in wave 3 were invited to participate and 2237 pupils $(87.7 \%)$ participated in the follow-up. For the analysis, the sample was restricted to 2192 
students who had participated in the follow-up and for whom information on educational attainment at upper secondary level was available.

To avoid loss of cases and hence statistical power, the data was multiply imputed using chained equations (Allison 2001; White et al. 2011). Full information was available for the following variables: the educational situation directly after as well as 15 months after completion of compulsory education, the scaling variable of the regional opportunity structures, gender and attended school type at lower secondary level. The following variables are imputed (\# missing values): GPA in German (160 Obs.) and mathematics (195 Obs.), parental social class (EGP; 165 Obs.) and educational level (361 Obs.) as well as pupils' educational aspirations from mid 8th grade (138 Obs.). Since we use grades in standardized form in the analysis, the "just another variable" (JAV) approach is used to impute missing values on GPA. Additionally, information on the sampling structure (strata, class) was used for data imputation. The convergence of the imputation model and the specifications of the number of iterations for the burn-in period is assessed using trace line plots. We use 30 iterations for the burn-in period. The multivariate and descriptive analyses are based on 50 imputed data sets.

To account for regional opportunity structures, we use data from the Swiss Federal Statistical Office (FSO) at the MS-regional level. The total of 106 MS-regions (spatial mobility regions; $\mathrm{MS}=$ mobilité spatiale) are characterized by a certain spatial homogeneity and reflect the principle of small-partially cross-cantonal-labor market areas with functional orientation towards centers (Schuler and Joye 2000; Schuler et al. 2005; BFS 2011). As the analyses are restricted to German-speaking cantons, information on 56 MS-regions was relevant and could be used (see Fig. 3 in the Appendix for an overview of the MS-regions included in the analysis). If data were available at the community level, those data have been aggregated at the MS-regional level.

\section{Operationalization}

The training places attended immediately after as well as 15 months after leaving compulsory education are used as dependent variables. Three educational outcomes are differentiated: (1) VET programs including EBA, EFZ, and FVB; (2) continued general education including specialized and baccalaureate schools; (3) bridge year courses that do not lead to a certified upper secondary qualification (10th school year, au-pair, preapprenticeships, preparatory courses, etc.). Descriptive statistics of the dependent and independent variables are provided in the Appendix (see Tables 4 and 5).

The following independent variables are used in the analysis. Pupils' social background is operationalized with the EGP-Class-Scheme (Erikson et al. 1979) and with parental education categorized according to the ISCED97-classification-scheme. Information on the EGP-class, as well as the ISCED-level is based on students' self-reporting in wave 3. If information for both parents is available, the higher EGP-class was used. Although the EGP-class of the parents and their attained educational degree could be biased when based on students' reporting, there is evidence that the reliability of child reports on parental occupation is high, whilst this applies to a lesser extent to parental educational level (Jerrim and Micklewright 2014; Engzell and Jonsson 2015). This is one reason why parents' reports on their occupational status and educational level, which were also collected in wave 1, are not used. Another reason is that nonresponse and 
item-nonresponse are lower when child reports are used. To account for the fact that child reports on parental education are less reliable, a rather crude categorization is used in which pupils whose parents had attained a tertiary degree are compared with those whose parents had attained a lower educational level.

As control variables for school performance, we use GPA in German and mathematics. GPA information was provided by class teachers. Grades in Switzerland usually rank from 1 to 6,6 being the highest possible grade and 4 the minimum requirement. Although school grades are no objective measure and may be biased, GPAs were used for two reasons. First, for reasons of compliance with the participating teachers in the DAB panel study, the implementation of an objective, teacher independent performance test was resigned. Second, grades are the main selection criteria for admittance to specialized and baccalaureate schools. Grades are used in $z$-standardized form in the analyses. To account for institutional effects on educational attainment, the school type attended at lower secondary level is used as a control variable.

Additionally, we control for gender as well as for pupils' realistic educational aspirations as measured in the mid 8th grade. The realistic educational aspirations are used as a crude measurement of the secondary effects of stratification. This variable nonetheless reflects pupils' subjective perception of the costs and benefits of different educational outcomes. Pupils were first asked what kind of upper secondary education they would like to begin after 9th grade if they could decide solely according to their wishes (idealistic educational aspiration). They were then asked: "And if you are being realistic, what do you think you will actually do after the 9th grade?". Pupils' responses to this question are used to differentiate whether their aim was to begin VET, to continue with general education, or to begin a bridge year course for the time being. We use information on realistic aspirations from the mid 8th grade for two reasons. On the one hand, realistic educational aspirations are influenced by the given structural constraints, e.g. the regional opportunity structures (Paulus and Blossfeld 2007). On the other hand, a high proportion of pupils who opt for general education enter pre-gymnasium already after the 8th grade and will then continue with a baccalaureate school. For these pupils, information on educational aspirations must be used from before the transition to pre-gymnasium.

In the analyses, we use one $z$-standardized scaling variable to control for regional opportunity structures. In the scaling variable, various aspects of the regional labor market structures and conditions are reflected in terms of the total and the proportion of workplaces in the second and third sector, the proportion of new jobs that have been created within new firms in recent years, and the regional unemployment rate. Additionally, we use the proportion of apprentices among employees, as well as the proportion of persons entitled to enroll at universities in order to capture pull factors that might influence pupils to follow specific educational pathways. As a measure of the competition among youths for high-demand training places, we use the youth ratio in the year 2000 as well as the change in the youth ratio within the years 2000-2010.

The scaling variable is the result of a principal-component factor analysis (PCF, see Harman 1976, 136ff.) in which we finally used ten variables that were selected on the basis of theoretical considerations and statistical quality criteria. Concerning the latter 
aspect, the overall Kaiser-Meyer-Olkin measure of sampling adequacy $(\mathrm{KMO}=0.813)$, as well as the KMO values of each of the variables used, are at least middling $(\mathrm{KMO}>0.8)$ and Bartlett's test of sphericity is highly significant. Based on the results of the parallel analysis (see Horn 1965; Dinno 2009), one latent factor was extracted for which we present the statistical quality criteria below (see Table 1).

With the exception of the variable «proportion of work places in the second sector», all factor loadings are over 0.733 , and communalities $(=1-$ uniqueness $)$ are higher than 0.538 . Factor loadings are negative for three variables: «youth ratio», «proportion of apprentices among all employees and apprentices» as well as «proportion of work places in the second sector», whereas the factor loadings of the remaining variables are positive. The average item-rest correlation and Cronbach's $\alpha$ were computed with standardized items. The reliability coefficient of the generated scaling variable-as our measurement of the regional opportunity structure-is excellent $(\alpha=0.939)$.

Overall, the highest values on the scaling variable are observed for the most urban regions with a comparatively low (high) proportion of workplaces in the second (third) sector and places in which most new jobs within new firms have been created in recent years. Additionally, these regions are characterized by a rather low proportion of apprentices among employees but a high proportion of persons that are entitled to enroll at universities. Besides a wide range of opportunities within the VET-system, these regions offer the broadest supply of general education (see Fig. 4 for a graphic representation of the distribution of the scaling variable).

\section{Statistical procedure}

Since we analyze the educational situation immediately after leaving compulsory schooling as well as 15 months afterwards, the analyses are conducted in two steps using multinomial logistic regression models (Long and Freese 2014). We use average marginal effects (AMEs) to compare nested models and to minimize bias related to unobserved heterogeneity (Mood 2010; Best and Wolf 2012). With regard to our dependent variables, AMEs provide an estimate of the population-averaged marginal effect of the independent variables on the probability of attending a specific educational track.

\section{Results}

\section{Educational situation after leaving compulsory education}

Immediately after compulsory education, the distribution of the dependent variable is as follows: $63 \%$ of the school leaver cohort from summer 2013 had commenced VET, $21 \%$ a baccalaureate or specialized school, and $16 \%$ were unable to directly commence with a certifying upper secondary track (see Table 5). As expected, the institutional setting strongly determines and channels educational attainment at upper secondary level (see model 1 in Table 2). Compared to pupils of the school type with basic requirements, pupils of the school type with advanced requirements or those of the pre-gymnasium have a significantly lower probability of commencing vocational education or a bridge year course, whereas their probability of continuing with general education is increased. The results related to effects at the individual level are in line with the findings of previous studies. Compared to their male counterparts, females' probability of commencing 
Table 1 Results of the principal-component factor analysis

\begin{tabular}{|c|c|c|c|c|}
\hline Indicators of regional opportunity structures & $\begin{array}{l}\text { Factor } \\
\text { loadings }\end{array}$ & $\begin{array}{l}\text { Unique- } \\
\text { ness }\end{array}$ & $\begin{array}{l}\text { Average item- } \\
\text { rest correlation }\end{array}$ & $\begin{array}{l}\alpha \text { without } \\
\text { item } i\end{array}$ \\
\hline Youth ratio, $2000^{\mathrm{a}}$ & -0.856 & 0.267 & 0.813 & 0.929 \\
\hline Change in youth ratio between 2000 and $2010^{b}$ & 0.826 & 0.318 & 0.777 & 0.931 \\
\hline Overall unemployment rate, $2013^{c}$ & 0.738 & 0.456 & 0.671 & 0.936 \\
\hline $\begin{array}{l}\text { Prop. of persons entitled to enroll at university on } \\
\text { all upper secondary qualifications, } 2013^{d}\end{array}$ & 0.762 & 0.419 & 0.707 & 0.935 \\
\hline $\begin{array}{l}\text { Prop. of apprentices among all employees and } \\
\text { apprentices, } 2012^{\mathrm{e}}\end{array}$ & -0.839 & 0.295 & 0.793 & 0.930 \\
\hline Total workplaces in the second sector, $2013^{f}$ & 0.733 & 0.462 & 0.667 & 0.936 \\
\hline Total workplaces in the third sector, $2013^{9}$ & 0.869 & 0.245 & 0.834 & 0.928 \\
\hline Prop. of workplaces in the second sector, $2013^{\mathrm{h}}$ & -0.673 & 0.547 & 0.605 & 0.939 \\
\hline Prop. of workplaces in the third sector, $2013^{i}$ & 0.884 & 0.218 & 0.849 & 0.928 \\
\hline $\begin{array}{l}\text { Prop. of new jobs created in new firms between } \\
2001-2012 \text { among all new jobs in new firms }\end{array}$ & 0.846 & 0.285 & 0.803 & 0.930 \\
\hline Eigenvalue & & & 6.488 & \\
\hline Proportion of variance accounted for by factor & & & 0.649 & \\
\hline Average interitem correlation & & & 0.605 & \\
\hline Number of items in the scale & & & 10 & \\
\hline Cronbach's $\alpha$ (standardized items) & & & 0.939 & \\
\hline
\end{tabular}

a Source: Statatlas Switzerland, FSO; map-id: 16, aggregated community level data based onFederal Population Census data b Source: Statatlas Switzerland, FSO; map-id: 15971, aggregated community level data based onFederal Population Census data and Population and Households Statistics (STATPOP)

c Source: Statatlas Switzerland, FSO; map-id: 17738, MS-regional level data based on Structuralsurvey and Unemployment Statistics (SECO)

d Source: Structural survey; requested at FSO

e Source: MS-regional level data based on Statistik der Unternehmensstruktur (STATENT) andStatistik der beruflichen Grundbildung (SBG), requested at FSO

f Source: Statatlas Switzerland, FSO; map-id: 18182, aggregated community level data based onStatistik der Unternehmensstruktur (STATENT)

g Source: Statatlas Switzerland, FSO; map-id: 18185, aggregated community level data based onStatistik der Unternehmensstruktur (STATENT)

h, i Source: Statatlas Switzerland, FSO; map-id: 18182, 18185, aggregated community level databased on Statistik der Unternehmensstruktur (STATENT)

j Source: Statatlas Switzerland, FSO; map-id: 17735, MS-regional level data based on BusinessCensus (BC) and Statistik der Unternehmensdemografie (UDEMO)

VET is approximately twenty percentage points lower. On the other hand, the results indicate that on average-when controlling for GPA and social background-the proportion of young females that continue with general education is higher compared to males, but that the former also have difficulties in directly securing a certifying upper secondary training place upon completion of compulsory schooling (see Glauser 2015, 142f.). Better grades in German and mathematics increase the probability of continuing with general education, and protect against remaining without a certifying upper secondary training place.

The effects of parents' EGP-class and their educational level indicate that IEO at this educational transition can be observed even if the school type attended at lower secondary level and GPA are controlled. Pupils from socially underprivileged families (EGP-classes V/VI/VII) compared to those from the upper service class (EGP-class I) have a higher probability of commencing VET but a lower probability of continuing with general education. The same is evident in respect of parental educational level. The 
probability of pupils from parents with a tertiary degree continuing with general education is increased by approximately ten percentage points compared to pupils from parents without a tertiary degree.

The empirical results support the assumption that regional opportunity structures significantly affect pupils' educational attainment. A one standard deviation increase in the scaling variable reduces the probability that pupils have commenced VET by four percentage points, whereas the probability that pupils have continued with general education or commenced a bridge year course is increased by approximately $2 \%$ points. Important, in our view, is the fact that we observe a negative effect on the probability of pupils commencing VET and a positive effect in terms of continuing with general education, respectively. The results indicate that regional opportunity structures have an impact on the educational attainment net of individual resources and institutional restrictions. If the regional opportunity structures offer a broader range of feasible educational alternatives in terms of both vocationally as well as academically oriented upper secondary tracks, and the total as well as the relative proportion of workplaces in the third sector are comparatively high, then the probability of pupils commencing VET decreases. In addition, the regional opportunity structures are positively correlated with pupils' probability of commencing bridge year courses. What cannot be addressed is whether the results are indicating a stronger mismatch between the demand for and the supply of specific training places in regions with broader opportunity structures, or whether pupils, who reside in regions with a broader supply of such educational programs, make use of bridge year courses to improve their educational chances. In the latter case, pupils from regions with restricted opportunity structures may be pulled stronger to commence VET.

When we additionally control for the realistic educational aspirations of pupils approximately 18 months prior to completion of compulsory education, the explanatory power of the model is improved (see model 2). The strong effects indicate that the realistic educational aspirations are highly correlated with educational attainment during the transition to upper secondary education. If pupils aspired in mid 8th grade to continue with general education, then their probability of finally doing so is increased by $37 \%$ points, whereas their probability of commencing VET is decreased by approximately $40 \%$ points. When realistic aspirations are considered, the effects of the school type attended at lower secondary level remain significant in most cases, but the magnitude of the effects declines substantially. This also applies partially to school performance. Better grades in mathematics do not increase the probability of continuing with general education but of commencing VET. The opposite is true in terms of grades in German. Social origin effects are reduced but remain statistically significant. However, the lower probability of commencing vocational education of pupils from parents with a tertiary degree is insignificant. This likewise applies to the gender effect in terms of continuing with general education. Unchanged is the finding that females' probability of commencing bridge year courses is higher compared to men. Either the aim of young females is to improve their chances of attaining a general education program, or there is a mismatch between the supply of VET programs and the demands of young females.

With regard to the effects of the regional opportunity structures, only part of the direct effects on educational attainment can be explained. In our view, the results nonetheless 


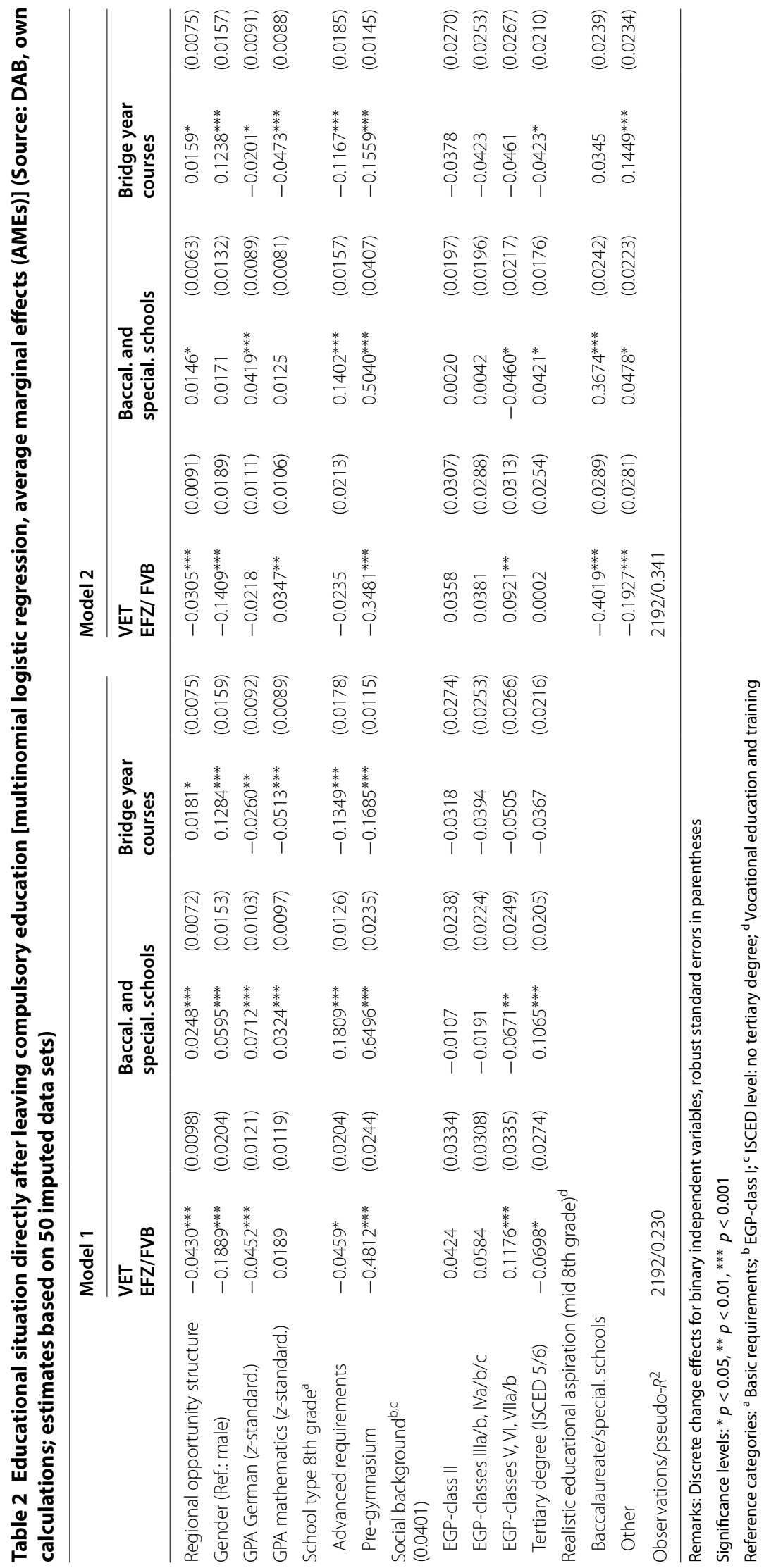


indicate that the regional opportunity structures are perceived, subjectively evaluated, and incorporated in pupils' realistic educational aspirations. This assumption is supported by analyses in which the educational aspiration is used as a dependent variable (see Table 6 in the Appendix). A one standard deviation increase in the scaling variable reduces the probability that pupils will aspire to attend VET, while the opposite holds true in terms of aspiring to attend general education programs. Furthermore, there is no direct effect of regional opportunity structures on the probability of pupils aspiring to commence bridge year courses. The insignificant effect is not surprising, since the aim of the pupils and their parents is to secure a certifying upper secondary training place.

\section{Educational situation 15 months after leaving compulsory education}

In the final step of the analysis, the focus is on the educational situation 15 months after leaving compulsory education. The distribution of the dependent variable is as follows: $74 \%$ of the pupils in our sample attended VET, $21 \%$ a baccalaureate or specialized school, and only $4 \%$ were unable to secure a certifying upper secondary training place (see Table 5). The vast majority of pupils who attended bridge year courses after leaving compulsory education commenced VET. Almost unchanged is the proportion of pupils that attended general education programs. The distribution is consistent with the findings of other studies and administrative data (Hupka 2003; SKBF 2014).

Overall, the direction of the effects outlined in the previous section remains unchanged (see model 1 in Table 3). As before, we find strong effects of the school type attended at lower secondary level on educational attainment 15 months after leaving compulsory education. The results confirm that better grades-particularly in German-reduce the probability of pupils attending VET but increase the probability of them attending a general education program. However, only better grades in mathematics significantly reduce the probability of remaining without a certifying training place. As before, the gender effects related to the probability of attending VET, baccalaureate schools and bridge year courses are significant. With respect to social origins, the results confirm that pupils from socially underprivileged families (EGP-classes V/VI/VII) have a higher probability of attending VET and a lower probability of attending general education programs compared to pupils from families of the upper service class (EGP-class I). It is no different in relation to the educational level of the parents. The probability of pupils from parents with a tertiary degree attending general education programs is increased by approximately $10 \%$ points compared to pupils from poorly educated social strata. These results demonstrate that within the Swiss educational system, the educational and thus in part the occupational inheritance is evident (see Becker 1997; Becker and Schuchart 2010; Lörz 2012). Pupils from parents that have obtained at most an upper secondary degree and therefore, in the majority, vocational qualifications, are likely to tread the same educational path, although this does not necessarily imply that the same professional qualifications are acquired. This equally applies to pupils whose parents have attained a tertiary degree. Since baccalaureate and specialized schools usually lead to matriculation certificates, a high proportion of these pupils will likewise attain a tertiary degree.

Finally, and as has been outlined in regards to the educational situation immediately after leaving compulsory schooling, the results confirm that the regional opportunity structures affect the educational attainment net of institutional constraints and 
individual resources. Regional opportunity structures have a significant negative effect in respect to the probability of attending VET and, conversely, a significant positive effect on the probability of pupils attending a general education program. However, if we additionally control for pupils' realistic educational aspirations in model 2 , the direct effects of the opportunity structures are narrowed but still significant. The results differ from those presented for the educational situation after leaving compulsory schooling, in which the the positive effect on the probability of attending bridge year courses is significant. Since only a minority of a school-leaver cohort is not able to realize a certifying upper secondary training place within 15 months after leaving compulsory education, it is not surprising that institutional (attended school type at lower secondary level) and individual constraints (GPA) matter more than the regional opportunity structure.

In line with the theoretical arguments related to secondary effects of stratification, the effect of parental social class is explained completely, once we account for pupils' realistic educational aspirations. In contrast, parental education has a stronger direct effect on pupils' educational attainment. As reported previously, the gender effect related to the probability of attending general education is no longer significant, indicating that part of this effect is reflected within pupils' educational aspirations and that females, for various reasons, are more strongly diverted from VET while this educational pathway seems to offer better prospects for males.

\section{Discussion and conclusion}

The aim of this paper was to address whether regional opportunity structures have an impact on educational attainment net of institutional and individual restrictions and how opportunity structures influence pupils' educational attainment. In answering these questions, we have used data from the DAB panel study enriched with administrative data from the Swiss Federal Statistical Office at the MS-regional level. With this data, we have analyzed the educational situation of pupils that left compulsory education in the summer of 2013 in German-speaking Switzerland. In regards to educational attainment immediately after and 15 months after leaving compulsory schooling, we have differentiated between VET, general education programs, and bridge year courses. To account empirically for variation in the regional opportunity structures, we have constructed one scaling variable based on principal component factor analysis. In the scaling variable, various aspects of the regional labor market structures and conditions, as well as the diversity and extent of the supply of educational alternatives, were considered.

Our findings indicate that regional opportunity structures have a direct effect on the upper secondary track attended. In addition to the effects of the school type attended at lower secondary level and individual constraints, we found that the more extensive the regional opportunity structures are, the higher the probability of pupils attending general education programs. In contrast, restricted opportunity structures increase pupils' probability of attending VET programs. Moreover, the regional opportunity structures are positively correlated with pupils' probability of commencing bridge year courses directly after leaving compulsory schooling. In our view, the varying results in regards to educational attainment immediately after leaving compulsory schooling are related to the fact that, at this stage, bridge year courses are of greater importance. Pupils from regions with restricted opportunity structures have fewer options to commence bridge 


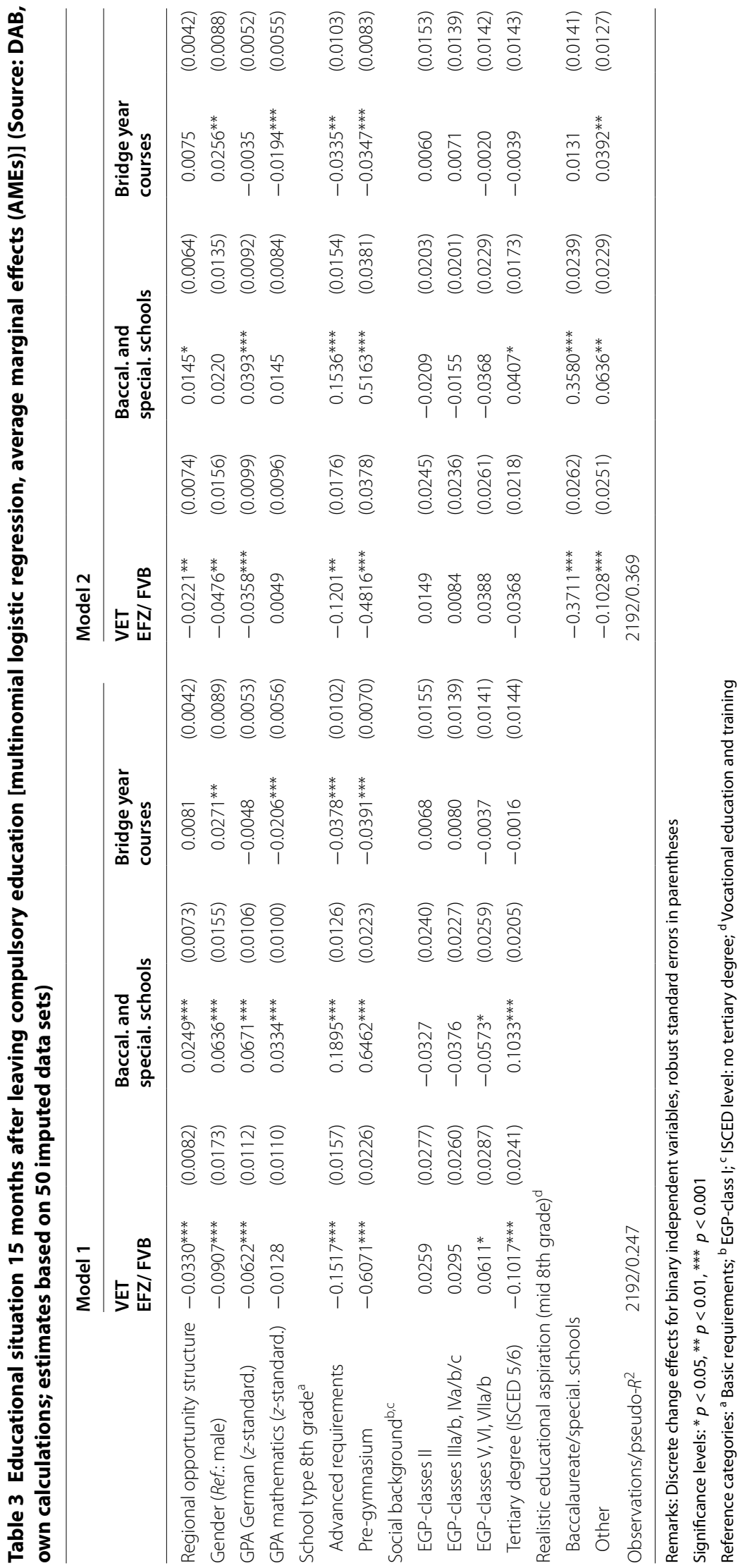


year courses and may, therefore, be forced to commence VET. We have argued in the theoretical section that, on the one hand, regions with broader opportunity structures provide a wide range of-vocational and general-education alternatives. On the other hand, this aspect is correlated with the regional labor market structure and prospects of labor market entry with occupation-specific or general qualifications. We could demonstrate that pupils who reside in regions with rather restricted opportunity structures are diverted from general education programs.

In addition, the analysis supports our assumption that pupils perceive and subjectively evaluate regional opportunity structures, which thus organize pupils' sets of feasible actions. In this context, we could demonstrate that the regional opportunity structures have an effect on pupils' realistic educational aspirations. Once we control for educational aspirations in the multivariate analyses, part of the direct effects of the opportunity structures on educational attainment after compulsory schooling can be explained. However, since the effects of the regional opportunity structures remain significant this implies that the real regional supply of educational opportunities structures the transitions to VET. While the aspirations are significant push factors, the regional supply of vocational and general educational alternatives could be isolated as pull factors for school leavers.

To our knowledge, this is the first study related to the impact of regional opportunity structures on educational aspirations and educational attainment at the transition to upper secondary education. Although we could demonstrate that educational aspirations and educational attainment are correlated with opportunity structures, there are several limitations of the study. First, the scaling variable that we used as a proxy for opportunity structures is far from perfect. For example, we used the proportion of apprentices among all employees and apprentices as a proxy for the supply of VET programs, because, to date, data on apprenticeship openings are not available. It is of utmost importance that data on the regional supply of apprenticeships are collected and provided to the scientific community. Second, with the data and sample used, the findings cannot be generalized to French- and Italian-speaking areas of Switzerland. Third, since we observe the transition into upper secondary education for a single school-leaver cohort only, the question of whether educational aspirations raise and fall with changes in the opportunity structures cannot be addressed. Fourth, we did not control for selection effects, i.e., parents' strategic choice of residence related to the supply of specific educational alternatives. However, there is evidence that the probability for residential mobility is increased by events such as gaining employment, marriage, or early family planning, while residential mobility is less likely for families (Eluru et al. 2009). Finally, it would be promising for further research to additionally account for variation of neighboring regions to better capture the impact of the spatial structure of opportunity structures on educational outcomes.

Authors' contributions

All authors read and approved the final manuscript.

Author details

${ }^{1}$ Institute of Educational Science, University of Bern, Fabrikstrasse 8, 3012 Bern, Switzerland. ${ }^{2}$ Department of Sociology of Education, Institute of Educational Science, University of Bern, Fabrikstrasse 8, 3012 Bern, Switzerland.

Acknowledgements

We would like to thank Christoph Zangger, University of Bern, the guest editor Stephan Schumann, University of Konstanz and the anonymous reviewers for their valuable advice during the elaboration of this article. Thank go to Riccarda Neff and Adrien Làzàr for their assistance in the collection of data on the regional opportunity structures. 


\section{Competing interests}

The authors declare that they have no competing interests.

\section{Funding}

The DAB panel study is substantially financed by the State Secretariat for Education, Research and Innovation (SERI). The interpretations and conclusions are those of the authors and do not necessarily represent the views of the SERI.

\section{Appendix}

See Figs. 2, 3 and 4 and Tables 4, 5 and 6.

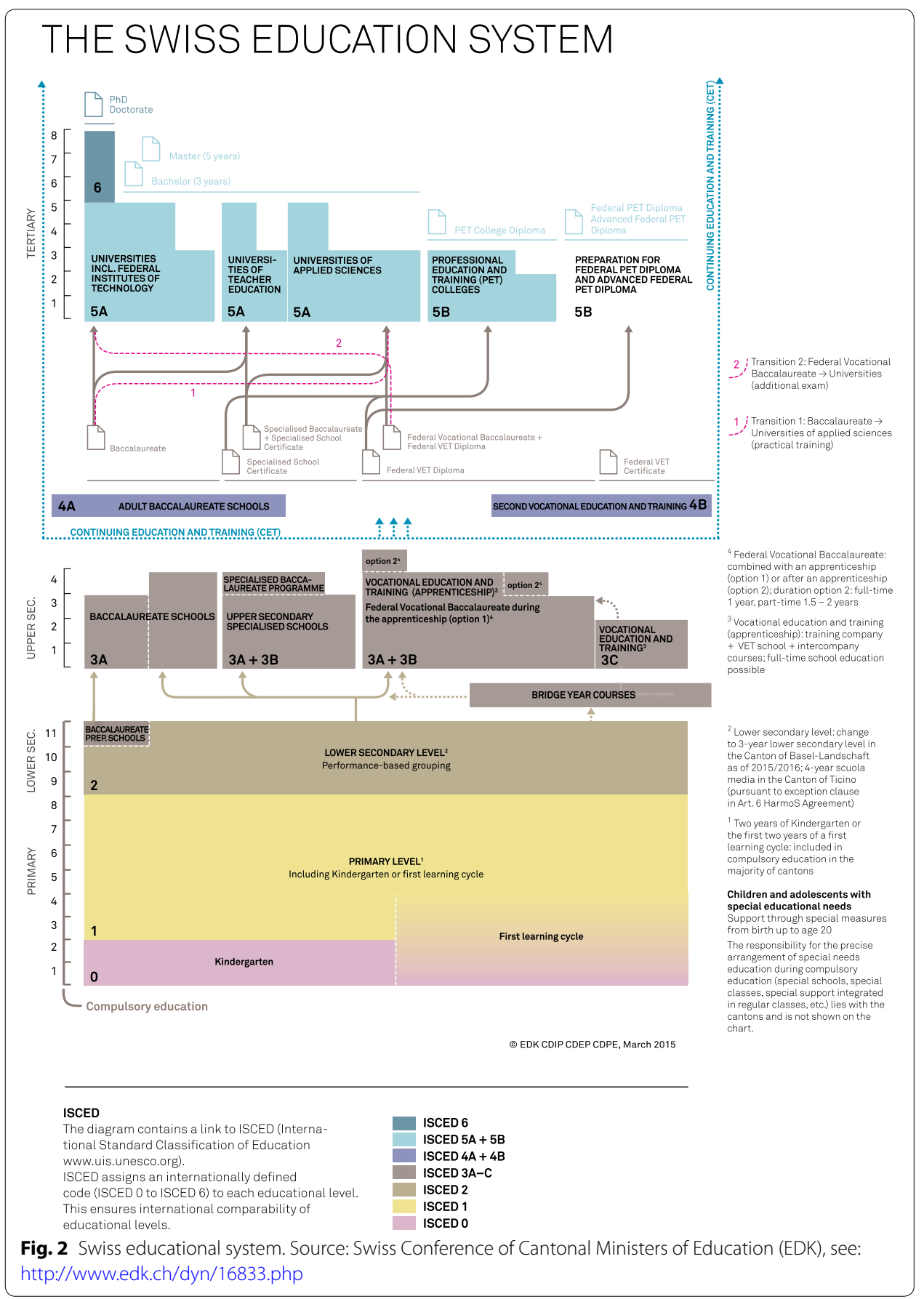




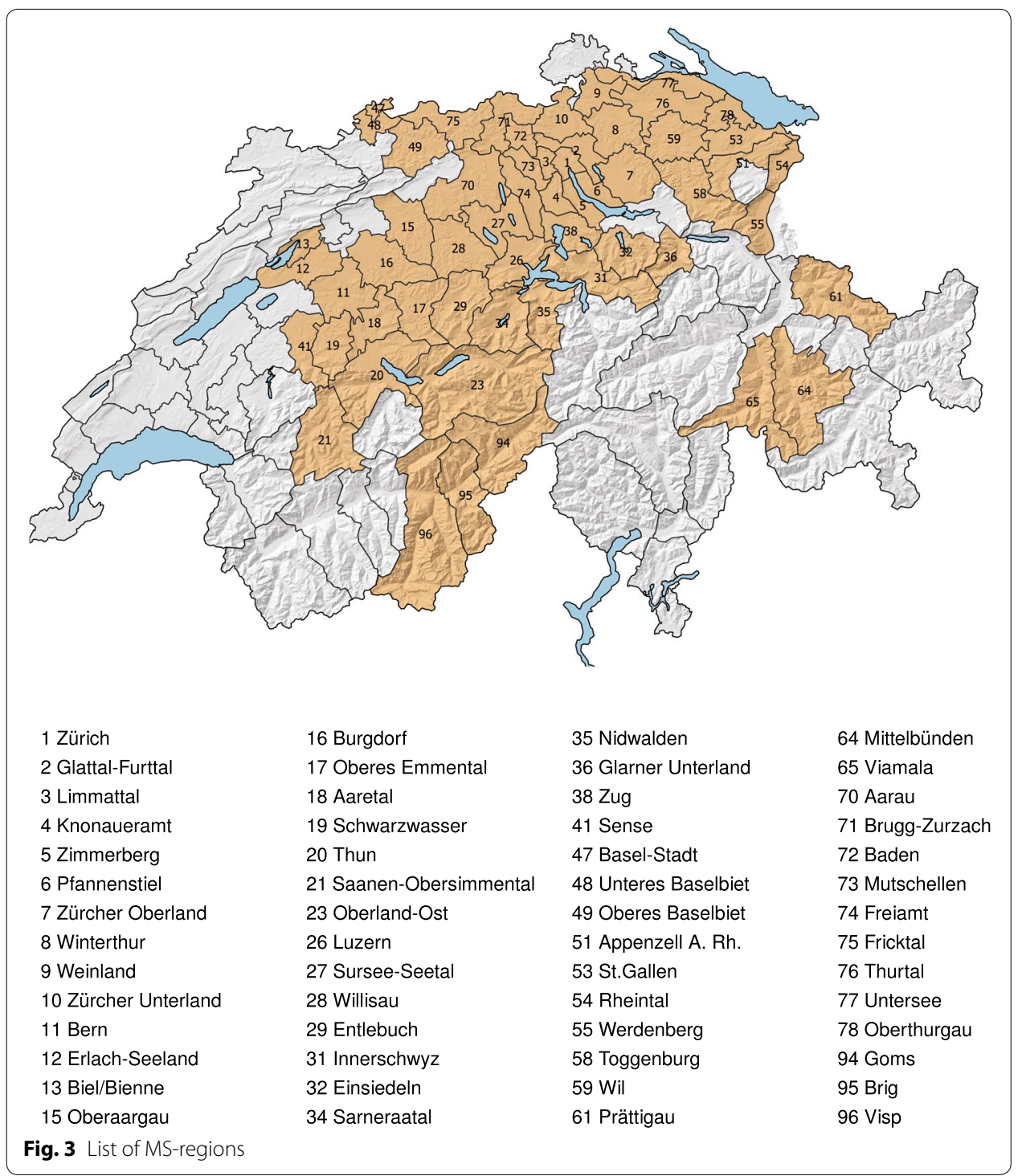




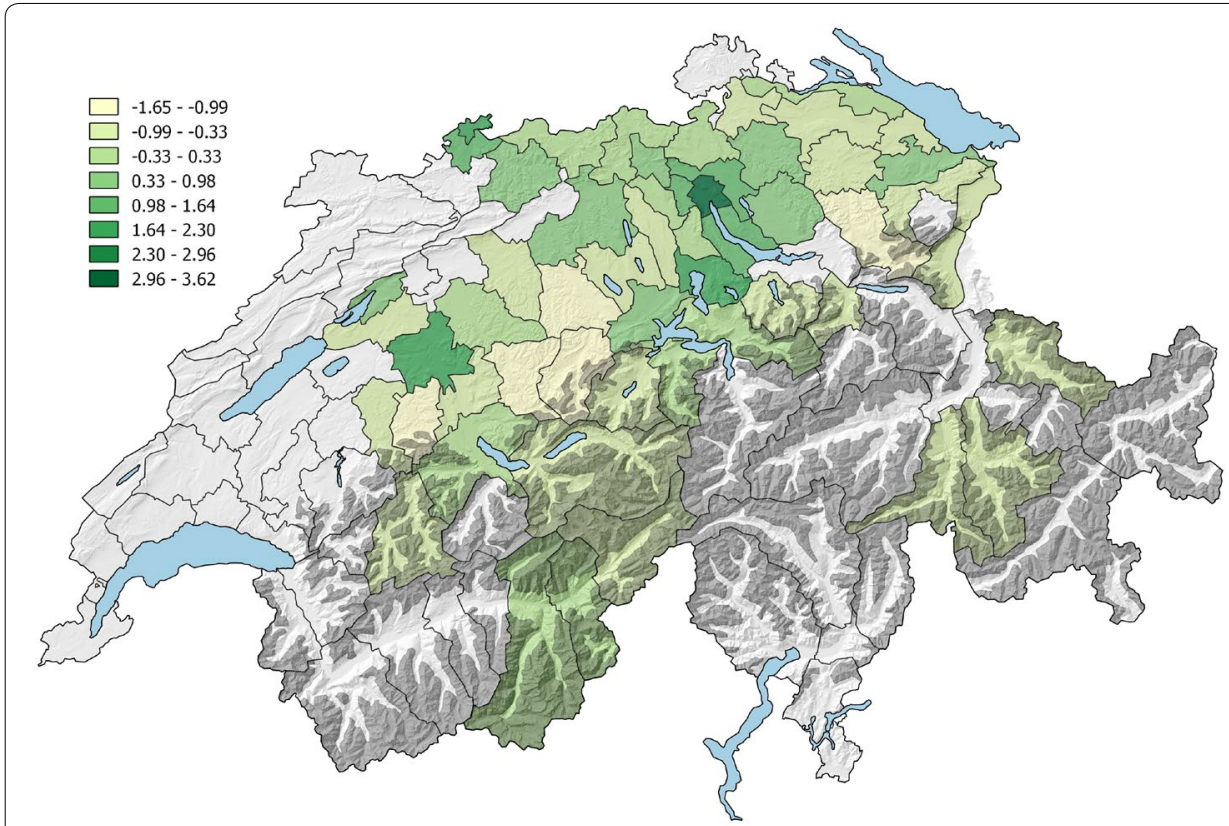

Fig. 4 Distribution of the scaling variable representing regional opportunity structures

Table 4 Descriptive statistics of (unstandardised) items used to construct the scaling variable representing regional opportunity structures ( $N=56$ MS-regions) (Source: see Table 1)

\begin{tabular}{|c|c|c|c|}
\hline & Mean & SD & Min./max. \\
\hline Youth ratio, year 2000 & 42.8 & 5.7 & $23.9 / 57.5$ \\
\hline Change in youth ratio between 2000 and 2010 & -7.9 & 4.4 & $-16.7 / 1.9$ \\
\hline Unemployment rate, year 2013 & 2.4 & 0.7 & $0.5 / 4.3$ \\
\hline $\begin{array}{l}\text { Prop. of persons entitled to enrol at university among all } \\
\text { upper secondary qualifications, } 2013\end{array}$ & 19.0 & 5.7 & $9.6 / 38.7$ \\
\hline $\begin{array}{l}\text { Prop. of apprentices among all employees and apprentices, } \\
2012\end{array}$ & 6.3 & 1.1 & $3.8 / 8.9$ \\
\hline Number of workplaces in the second sector, 2013 & 1340.8 & 768.8 & $96 / 2850$ \\
\hline Number of workplaces in the third sector, 2013 & 7316.1 & 6529.7 & $399 / 38,909$ \\
\hline Prop. of workplaces in the second sector, 2013 & 15.8 & 3.1 & $6.4 / 22.9$ \\
\hline Prop. of workplaces in the third sector, 2013 & 72.3 & 11.2 & $38.7 / 93.5$ \\
\hline $\begin{array}{l}\text { Prop. of new jobs created in new firms between 2001-2012 } \\
\text { among all new jobs in new firms }\end{array}$ & 1.4 & 1.4 & $.03 / 9.3$ \\
\hline
\end{tabular}


Table 5 Descriptive statistics of Tables 2 and $3(N=2192)$ (Source: DAB, own calculations; estimates based on 50 imputed data sets)

\begin{tabular}{|c|c|c|c|}
\hline & $\begin{array}{l}\text { Mean/ } \\
\text { Proportion }\end{array}$ & SD & $\begin{array}{l}\text { Min./max./ } \\
95 \% \mathrm{Cl}\end{array}$ \\
\hline \multicolumn{4}{|l|}{ Dependent variables } \\
\hline \multicolumn{4}{|l|}{ Educ. situation after leaving comp. educ. } \\
\hline Vocational education and training & 0.625 & & $0.605 ; 0.646$ \\
\hline Baccalaureate/specialized school & 0.213 & & $0.195 ; 0.230$ \\
\hline Bridge year courses & 0.162 & & $0.147 ; 0.177$ \\
\hline \multicolumn{4}{|c|}{ Educ. situation 15 months after comp. educ. } \\
\hline Vocational education and training & 0.744 & & $0.726 ; 0.762$ \\
\hline Baccalaureate/specialized school & 0.213 & & $0.196 ; 0.230$ \\
\hline Bridge year courses & 0.043 & & $0.034 ; 0.051$ \\
\hline \multicolumn{4}{|l|}{ Independent variables } \\
\hline Regional opportunity structure & 0.219 & 0.981 & $-1.649 / 3.623$ \\
\hline Gender: female & 0.518 & & $0.497 ; 0.539$ \\
\hline \multicolumn{4}{|l|}{ School performance } \\
\hline GPA German & 0.093 & 0.959 & $-6.206 / 2.974$ \\
\hline GPA Mathematics & 0.072 & 0.969 & $-5.434 / 2.731$ \\
\hline \multicolumn{4}{|l|}{ School type 8th grade } \\
\hline Basic requirements & 0.300 & & $0.281 ; 0.319$ \\
\hline Advanced requirements & 0.578 & & $0.557 ; 0.599$ \\
\hline Pre-gymnasium & 0.122 & & $0.108 ; 0.136$ \\
\hline \multicolumn{4}{|l|}{ EGP-class parents } \\
\hline EGP-class I & 0.172 & & $0.155 ; 0.188$ \\
\hline EGP-class II & 0.224 & & $0.206 ; 0.243$ \\
\hline EGP-classes IIla/b, IVa/b/c & 0.359 & & $0.338 ; 0.380$ \\
\hline EGP-classes V, VI, Vlla/b & 0.245 & & $0.226 ; 0.264$ \\
\hline \multicolumn{4}{|l|}{ ISCED level parents } \\
\hline No tertiary degree (ISCED 2/4) & 0.801 & & $0.783 ; 0.819$ \\
\hline Tertiary degree (ISCED 5/6) & 0.199 & & $0.181 ; 0.217$ \\
\hline \multicolumn{4}{|l|}{ Educational aspiration in mid 8th grade } \\
\hline Vocational education and training & 0.587 & & $0.566 ; 0.608$ \\
\hline Baccalaureate/specialized school & 0.237 & & $0.219 ; 0.255$ \\
\hline Other & 0.176 & & $0.159 ; 0.192$ \\
\hline
\end{tabular}


Table 6 Determinants of realistic educational aspirations [multinomial logistic regression, average marginal effects (AMEs)] Source: DAB, own calculations; estimates based on 50 imputed data sets

\begin{tabular}{|c|c|c|c|c|c|c|}
\hline \multirow[b]{2}{*}{$\begin{array}{l}\text { Regional opportunity } \\
\text { structure }\end{array}$} & \multicolumn{2}{|l|}{$\begin{array}{l}\text { VET } \\
\text { EFZ/FVB }\end{array}$} & \multicolumn{2}{|c|}{$\begin{array}{l}\text { Baccal. and } \\
\text { special. schools }\end{array}$} & \multicolumn{2}{|l|}{ Other } \\
\hline & $-0.0352^{* * *}$ & $(0.0105)$ & $0.0244^{* *}$ & $(0.0085)$ & 0.0107 & $(0.0083)$ \\
\hline Gender (Ref:: male) & $-0.1051^{* * *}$ & $(0.0219)$ & $0.0845^{* * *}$ & $(0.0172)$ & 0.0206 & $(0.0172)$ \\
\hline \multicolumn{7}{|l|}{ School performance } \\
\hline GPA German (z-standard.) & $-0.0287^{*}$ & $(0.0129)$ & $0.0582^{* * *}$ & $(0.0113)$ & $-0.0295^{* *}$ & $(0.0098)$ \\
\hline $\begin{array}{l}\text { GPA mathematics } \\
\text { (z-standard.) }\end{array}$ & -0.0158 & $(0.0124)$ & $0.0415^{* * *}$ & $(0.0108)$ & $-0.0257^{* *}$ & $(0.0096)$ \\
\hline \multicolumn{7}{|l|}{ School type 8th grade ${ }^{\mathrm{a}}$} \\
\hline Advanced requirements & -0.0063 & $(0.0236)$ & $0.1669^{* * *}$ & $(0.0175)$ & $-0.1606^{* * *}$ & $(0.0199)$ \\
\hline Pre-gymnasium & $-0.3406^{* * *}$ & $(0.0328)$ & $0.5033^{* * * *}$ & $(0.0328)$ & $-0.1628^{* * *}$ & $(0.0141)$ \\
\hline \multicolumn{7}{|l|}{ EGP-class parents ${ }^{\mathrm{b}}$} \\
\hline EGP-class II & -0.0127 & $(0.0365)$ & -0.0235 & $(0.0281)$ & 0.0362 & $(0.0290)$ \\
\hline EGP-classes IIIa/b, IVa/b/c & 0.0328 & $(0.0335)$ & -0.0378 & $(0.0253)$ & 0.0050 & $(0.0265)$ \\
\hline EGP-classes V, VI, VIla/b & 0.0610 & $(0.0356)$ & -0.0392 & $(0.0290)$ & -0.0218 & $(0.0275)$ \\
\hline \multicolumn{7}{|l|}{ ISCED level parents ${ }^{c}$} \\
\hline Tertiary degree (ISCED 5/6) & $-0.1653^{* * *}$ & $(0.0319)$ & $0.1315^{* * *}$ & $(0.0247)$ & 0.0338 & $(0.0276)$ \\
\hline Observations/pseudo- $R^{2}$ & $2192 / 0.141$ & & & & & \\
\hline
\end{tabular}

Remarks: Discrete change effects for binary independent variables, robust standard errors in parentheses

Significance levels: ${ }^{*} p<0.05,{ }^{* *} p<0.01,{ }^{* * *} p<0.001$

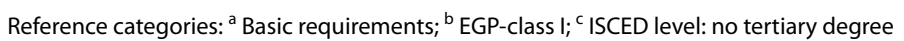

Received: 6 November 2015 Accepted: 20 June 2016

Published online: 15 July 2016

\section{References}

Allison PD (2001) Missing data. Sage University Press series on quantitative applications in the social scienes, vol 07-136. Sage, Thousand Oaks

BFS [Bundesamt für Statistik] (2011) Die Raumgliederungen der Schweiz 2011 - MS-Excel Version (be-b-00.04-rgs-01.xls). http://www.bfs.admin.ch/bfs/portal/de/index/infothek/nomenklaturen/blank/blank/gemtyp/01.html, [Bundesamt für Statistik]. Accessed 19 Sep 2014

BFS (2014) Bildungsabschlüsse Sekundarstufe II nach Sprachregion und Geschlecht, 1999-2013 (Dateien: je-d-15.03.02.01.01 und je-d-15.03.02.02.01) 2014-08-15. http://www.bfs.admin.ch/bfs/portal/de/index themen/15/04/00/blank/uebersicht.html. Accessed 15 Aug 2014

BFS (2015) Maturitätsquote nach Maturitätstyp und Wohnkanton, 2014 (File:T405102d d104_v8.xls). http://www.bfs. admin.ch/bfs/portal/de/index/themen/15/17/blank/01.indicator.405102.4085.html?. Accessed 27 Oct 2015

Becker R (1997) Generationen und sozialer Wandel - eine Einführung. In: (Hg.) Generationen und sozialer Wandel. Generationsdynamik, Generationenbeziehungen und Differenzierung von Generationen. Leske + Budrich, Opladen, pp 9-22

Becker R (2003) Educational expansion and persistent inequalities of education. Utilizing subjective expected utility theory to explain increasing participation rates in upper secondary school in the Federal Republic of Germany. Eur Soc Rev 19:1-24. http://esr.oxfordjournals.org/cgi/content/abstract/19/1/1

Becker R, Hadjar A (2013) Gesellschaftliche Kontexte, Bildungsverläufe und Bildungschancen, Springer Fachmedien, Wiesbaden, pp 511-553. doi:10.1007/978-3-531-18985-7_18

Becker R, Schuchart C (2010) Verringerung sozialer Ungleichheiten von Bildungschancen durch Chancenausgleich? Ergebnisse einer Simulation bildungspolitischer Maßnahmen, Vierte veränderte Auflage, VS Verlag für Sozialwissenschaften, Wiesbaden, pp 413-436

Becker R, Schulze A (2013) Bildungskontexte. Springer Fachmedien, Strukturelle Voraussetzungen und Ursachen ungleicher Bildungschancen, Wiesbaden

Becker R, Zangger C (2013) Die Bildungsexpansion in der Schweiz und ihre Folgen. Eine empirische Analyse des Wandels der Bildungsbeteiligung und Bildungsungleichheiten mit den Daten der Schweizer Volkszählungen 1970, 1980, 1990 und 2000. Kölner Zeitschrift für Soziologie und Sozialpsychologie 65:423-449 
Becker R, Japel F, Beck M (2013) Diskriminierung durch Lehrpersonen oder herkunftsbedingte Nachteile von Migranten im Deutschschweizer Schulsystem? Schweizerische Zeitschrift für Soziologie 39:517-549

Best H, Wolf C (2012) Modellvergleich und Ergebnisinterpretation in Logit- und Probit-Regressionen. Kölner Zeitschrift für Soziologie und Sozialpsychologie 64:377-395. doi:10.1007/s11577-012-0167-4

Blossfeld HP (1985) "Berufseintritt und Berufsverlauf: Eine Kohortenananlyse über die Bedeutung des ersten Berufes in der Erwerbsbiographie,"Mitteilungen aus der Arbeitsmarkt-und Berufsforschung, vol 18, pp 177-197. https://webvpn. unibe.ch/mittab/1985/,Danalnfo=doku.iab.de+1985_2_MittAB_Blossfeld.pdf

Blöchle SJ, Flake R, Khairi-Taraki T, Körbel M, Pierenkemper S, Rauland C, Werner D, Wörndl D (2015) Berufsausbildung für Europas Jugend. Voneinander lernen, miteinander gestalten (Studie zusammen mit der Hans-Böckler-Stiftung, der Konrad-Adenauer-Stiftung und der Vodafone Stiftung Deutschland), Technical report, Institut der deutschen Wirtschaft Köln

Boudon R (1974) Education, opportunity and social inequality. Wiley, Changing Prospects in Western Society, New York

Breen R, Goldthorpe JH (1997) Explaining educational differentials. Towards a formal rational action theory. Ration Soc 9:275-305

Breen $\mathrm{R}$, van de Werfhorst HG, Jæger MM (2014) Deciding under doubt. A theory of risk aversion, time discounting preferences, and educational decision-making. Eur Soc Rev 30:258-270. http://esr.oxfordjournals.org/content/30/2/258. abstract

Buchmann M, Sacchi S, Lamprecht M, Stamm H (2007) Tertiary education expansion and social inequality in Switzerland. Stanford University Press, Stanford, pp 321-348

Buchs H, Müller B, Buchmann M (2015) Qualifikationsnachfrage und Arbeitsmarkteintritt in der Schweiz. Kölner Zeitschrift für Soziologie und Sozialpsychologie 67:709-736. doi:10.1007/s11577-015-0342-5

Coleman JS (1986) Social-theory, social-research, and a theory of action. Am J Soc 91:1309-1335. http://www.jstor.org/ stable/2779798

Combet B (2013) Zum Einfluss von primären und sekundären Effekten der sozialen Herkunft beim zweiten schulischen Übergang in der Schweiz. Ein Vergleich unterschiedlicher Dekompositions- und Operationalisierungsmethoden. Ein Vergleich unterschiedlicher Dekompositions- und Operationalisierungsmethoden. Schweizerische Zeitschrift für Bildungswissenschaften 35:447-471

de Lange M, Gesthuizen M, Wolbers MHJ (2013) Youth labour market integration across Europe. Eur Soc 16:194-212. doi: $10.1080 / 14616696.2013 .821621$

Denzler S, Wolter SC (2008) Selbstselektion bei der Wahl eines Lehramtsstudiums. Zum Zusammenspiel individueller und institutioneller Faktoren. Beiträge zur Hochschulforschung 30:112-141

Dinno A (2009) Implementing Horn's parallel analysis for principal component analysis and factor analysis. Stata J 9:291-298. http://www.stata-journal.com/article.html?article=st0166

Eluru N, Sener I, Bhat C, Pendyala R, Axhausen K (2009) Understanding residential mobility. Transp Res Rec J Transp Res Board 2133:64-74. http://trrjournalonline.trb.org/doi/abs/10.3141/2133-07

Engzell P, Jonsson J (2015) Estimating social and ethnic inequality in school surveys. Biases from child misreporting and parent nonresponse. Eur Soc Rev 31:312-325. http://esr.oxfordjournals.org/content/31/3/312.abstract

Erikson RJJ (1996) Explaining class inequality in education: the Swedish test case. Westview Press, Boulder, pp 1-63

Erikson R, Rudolphi F (2010) Change in social selection to upper secondary school. Primary and secondary effects in Sweden. Eur Soc Rev 26:291-305. http://esr.oxfordjournals.org/content/26/3/291.abstract

Erikson R, Goldthorpe JH, Portocarero L (1979) Intergenerational class mobility in three western European societies. England, France and Sweden. Br J Soc 30:415-441. http://www.jstor.org/stable/589632

Falcon J (2012) Temporal trends in intergenerational social mobility in Switzerland. A cohort study of men and women born between 1912 and 1974. Swiss J Soc 38:153-175

Falter JM, Chávez Juárez F (2011) Does tracking shape intergenerational transmission of educational attainment? Evidence from Switzerland (Working-paper). http://ssrn.com/abstract=1938281. Accessed 19 Sept 2014

Fazekas M, Field S (2013) A skills beyond school review of Switzerland (Skills OECD: building the right skills and turning them into better jobs and better lives). OECD, Paris

Gangl M (2001) European patterns of labour market entry. A dichotomy of occupationalized vs. non-occupationalized systems? Eur Soc 3:471-494. doi:10.1080/14616690120112226

Glauser D (2012) Erwerbseintritt von gering qualifizierten Jugendlichen in der Schweiz: Unqualifzierte Beschäftigung und Einkommensnachteile im Vergleich zu Jugendlichen mit Berufsbildungsabschluss. Beltz Juventa, Weinheim, pp $231-250$

Glauser D (2015) Berufsausbildung oder Allgemeinbildung. Soziale Ungleichheiten beim Übergang in die Sekundarstufe II in der Schweiz. Springer VS, Wiesbaden. doi:10.1007/978-3-658-09096-8_2

Gonon P (2012) Entstehung und Dominanz der dualen Berufsausbildung in der Schweiz. Springer Fachmedien, Wiesbaden, pp 221-242. doi:10.1007/978-3-531-19071-6 11

Harman HH (1976) Modern factor analysis. University of Chicago Press, Chicago

Horn JL (1965) A rationale and test for the number of factors in factor analysis. Psychometrika 30:179-185. doi:10.1007/ BF02289447

Hupka S (2003) Ausbildungssituation und -verläufe. Übersicht. BFS, Neuchâtel

Imdorf C, Sacchi S, Wohlgemuth K, Cortesi S, Schoch A (2014) How cantonal education systems in Switzerland promote gender-typical school-to-work transitions. Schweizerische Zeitschrift für Soziologie 40:175-196

Jann B, Combet B (2012) Zur Entwicklung der intergenerationalen Mobilität in der Schweiz. Swiss J Soc 38:177-199

Jerrim J, Micklewright J (2014) Socio-economic gradients in children's cognitive skills. Are cross-country comparisons robust to who reports family background? Eur Soc Rev 30. http://esr.oxfordjournals.org/content/early/2014/08/25/ esr.jcu072.abstract

Karlson KB (2013) Summarizing primary and secondary effects. Res Soc Stratif Mobil 33:72-82. http://www.sciencedirect. com/science/article/

Kerckhoff AC (2001) Education and social stratification processes in comparative perspective. Soc Educ 74:3-18. http:// www.jstor.org/stable/2673250 
Kroneberg C, Kalter F (2012) Rational choice theory and empirical research. Methodological and theoretical contributions in Europe. Annu Rev Soc 38:73-92. doi:10.1146/annurev-soc-071811-145441

Long JS, Freese J (2014) Regression models for categorical dependent variables using Stata, 3rd edn. Stata Press, College Station

Lörz M (2012) Mechanismen sozialer Ungleichheit beim Übergang ins Studium: Prozesse der Status- und Kulturreproduktion. vol 52 of Kölner Zeitschrift für Soziologie und Sozialpsychologie Sonderhefte, Springer Fachmedien, Wiesbaden, pp 302-324. doi: 10.1007/978-3-658-00120-9_13

Maurice M, Sellier F, Silvestre JJ (1986) The social foundations of industrial power. MIT Press, A comparison of France and Germany, Cambridge

Meyer T (2003) Zwischenlösung - Notlösung?. BFS, Neuchâtel

Meyer T, Bertschy K (2011) The long and winding road from education to labour market. The TREE cohort six years after leaving compulsory school. Seismo, Zürich, pp 92-119

Mood C (2010) Logistic regression. Why we cannot do what we think we can do, and what we can do about it. Eur Soc Rev 26:67-82. http://esr.oxfordjournals.org/content/26/1/67.abstract

Murphy EC (2014) Workers' movement out of declining occupations in Great Britain, Germany and Switzerland. Eur Soc Rev 30:685-701. http://esr.oxfordjournals.org/content/early/2014/08/09/esr.jcu066.abstract

Mühlemann S, Wolter SC (2007) Regional effects on employer provided training: evidence from apprenticeship training in Switzerland. Zeitschrift für ArbeitsmarktForschung 40:135-147

Müller W, Kogan I (2010) Education. Springer, New York, pp 217-289. doi:10.1007/978-0-387-88199-7_9

Müller W, Pollak R (2007) Weshalb gibt es so wenige Arbeiterkinder in Deutschlands Universitäten?. VS Verlag für Sozialwissenschaften, Wiesbaden, pp 303-342

Müller B, Schweri J (2009) Berufswechsel beim Übergang von der Lehre in den Arbeitsmarkt. Schweizerische Zeitschrift für Bildungswissenschaften 31:199-227

Müller B, Schweri J (2015) How specific is apprenticeship training? Evidence from inter-firm and occupational mobility after graduation. Oxf Econ Papers. http://oep.oxfordjournals.org/content/early/2015/06/27/oep.gpv040.abstract

Müller W, Shavi Y (1998) The institutional embeddedness of the stratification process. A comparative study of qualifications and occupations in thirteen countries. Clarendon Press, Oxford

Müller B, Wolter SC (2014) The role of hard-to-obtain information on ability for the school-to-work transition. Empir Econ 46:1447-1474. doi:10.1007/s00181-013-0709-2

Müller W, Gangl M, Scherer S (2002) Übergangsstrukturen zwischen Bildung und Beschäftigung. Juventa, Weinheim

Müller W, Pollak R, Reimer D, Schindler S (2011) Hochschulbildung und soziale Ungleichheit. VS Verlag für Sozialwissenschaften, Wiesbaden, pp 289-327. doi:10.1007/978-3-531-92759-6_11

OECD (2015) OECD Publishing, Paris, doi: 10.1787/eag-2015-83-en

Oesch D (2013) Occupational change in Europe. Oxford University Press, How technology and education transform the job structure, Oxford

Paulus W, Blossfeld HP (2007) Schichtspezifische Präferenzen oder sozioökonomisches Entscheidungskalkül? Zur Rolle elterlicher Bildungsaspirationen im Entscheidungsprozess beim übergang von der Grundschule in die Sekundarstufe. Zeitschrift für Pädagogik 53:491-508

Pfeffer FT (2008) Persistent inequality in educational attainment and its institutional context. Eur Soc Rev 24:543-565. http://esr.oxfordjournals.org/content/24/5/543.abstract

Reimer D (2013) Kontexteffekte und soziale Ungleichheit beim übergang von der Schule zur Hochschule. Springer Fachmedien Wiesbaden, Wiesbaden, pp 405-429. doi:10.1007/978-3-531-18985-7_14

Rephann TJ (2002) The importance of geographical attributes in the decision to attend college. Socio Econ Plan Sci 36:291-307. http://www.sciencedirect.com/science/article/

Sacchi S, Hupka-Brunner S, Stalder BE, Gangl M (2011) Die Bedeutung von sozialer Herkunft und Migrationshintergrund für den Übertritt in anerkannte nachobligatorische Ausbildungen in der Schweiz. Seismo, Zürich

Salvisberg A, Sacchi S (2014) Labour market prospects of Swiss career entrants after completion of vocational education and training. Eur Soc 16:255-274. doi:10.1080/14616696.2013.821623

Samuel R, Bergman MM, Hupka-Brunner S (2014) Longitudinal effects of social background on educational and occupational pathways within early and strong school tracking. Longitud Life Course Stud 5:1-18

Schindler S (2014) Wege zur Studienberechtigung-Wege ins Studium?. Springer Fachmedien, Wiesbaden. doi:10.1007/978-3-658-03841-0

Schmelzer P (2012) The consequences of job mobility for future earnings in early working life in Germany. Placing indirect and direct job mobility into institutional context. Eur Soc Rev 28:82-95

Schuler M, Dessemontet P, Joye D (2005) Die Raumgliederung der Schweiz. BFS, Neuchâtel

Schuler M, Dominique JO (2005) Typologie der Gemeinden der Schweiz: 1980-2000. BFS, Neuchâtel

Schumann S (2011) Leistungs-und Herkunftseffekte beim Hochschulzugang in der Schweiz. Ein Vergleich zwischen Absolventinnen und Absolventen mit gymnasialer Maturität und mit Berufsmaturität. Zeitschrift für Pädagogik $57: 246-268$

Sheldon G (2008) Die Rolle der Berufsbildung in der Bekämpfung des Fachkräftemangels, Technical report. Universität Basel, Forschungsstelle für Arbeitsmarkt und Industrieökonomik

Sixt M (2013) Wohnort, Region und Bildungserfolg. Die strukturelle Dimension bei der Erklärung von regionaler Bildungsungleichheit. Springer Fachmedien Wiesbaden, Wiesbaden, pp 457-481. doi:10.1007/978-3-531-18985-7_16

SKBF [Schweizerische Koordinationsstelle fur Bildungsforschung] (2014) Bildungsbericht Schweiz 2014. SKBF, Aarau

Stalder BE, Meyer T, Hupka-Brunner S (2011) Leistungsschwach-bildungsarm? Ergebnisse der TREE-Studie zu den PISAKomepetenzen als Prädiktoren für Bildungschancen in der Sekundarstufe II. Seismo, Zärich, pp 201-216

Stocké V (2007) Explaining educational decision and effects of families social class position. An empirical test of the Breen Goldthorpe model of educational attainment. Eur Soc Rev 23:505-519. http://esr.oxfordjournals.org/cgi/content/ abstract/23/4/505

Stocké V (2010) Der Beitrag der Theorie rationaler Entscheidung zur Erklärung von Bildungsungleichheit. VS Verlag für Sozialwissenschaften, Wiesbaden. doi:10.1007/978-3-531-92576-9_4 
Weßling K, Hartung A, Hillmert S (2015) Spatial structure counts. The relevance of regional labour-market conditions for educational transitions to vocational training. Empir Res Vocat Educ Train 7:1-20. doi:10.1186/s40461-015-0024-6

White IR, Royston P, Wood AM (2011) Multiple imputation using chained equations: issues and guidance for practice. Stat Med 30:377-399

Wolter SC, Mühlemann S, Schweri J (2006) Why some firms train apprentices and many others do not. Ger Econ Rev 7:249-264. doi:10.1111/j.1468-0475.2006.00155.x

Zangger C (2015) The social geography of education. Neighborhood, class composition, and the educational achievement of elementary school students in Zurich, Switzerland. Zeitschrift für Soziologie 44:292-310

Submit your manuscript to a SpringerOpen ${ }^{\circ}$ journal and benefit from:

- Convenient online submission

Rigorous peer review

- Immediate publication on acceptance

Open access: articles freely available online

- High visibility within the field

- Retaining the copyright to your article

Submit your next manuscript at $\boldsymbol{\nabla}$ springeropen.com 